\author{
Zh.I. Kuanbay ${ }^{1}$, S.A. Abiyev ${ }^{1}$, V.N. Tikhomirov ${ }^{2}$ \\ ${ }^{1}$ L.N. Gumilyov Eurasian National University, Nur-Sultan, Kazakhstan; \\ ${ }^{2}$ Belarusian State University, Minsk, Belarus \\ (E-mail:zhenia_80@bk.ru)
}

\title{
The study of some structural parameters of the flora of chink Dongyztau (Aktobe region)
}

\begin{abstract}
The results of the study of structural indices of the flora of vascular plants chink Dongyaztau are presented in the article. According to the classification of life forms of I.G Serebryakov, the dominant share is occupied by perennial polycarpic herbs - 124 species, or $39.5 \%$, on the second position there are monocarpic herbs 123 species, or $39.1 \%$. Semi-wood species make up 43 species, or $13.7 \%$, wood forms -21 species, or $6.7 \%$. A high proportion of ephemera was noted which are 28 species, or $8.9 \%$. According to the classification of C. Raunkiaer in the flora chink Dongyztau is dominated by therophytes - 119 species, or $37.9 \%$. On the second place there is a group of hemi-cryptophytes - 104 species, or $33.1 \%$; in third place chameophytes (46 species, or $14.6 \%$ ); in the fourth position - cryptophytes ( 31 species, or $9.9 \%$ ); on the fifth - phanerophytes (14 species, or $4.5 \%$ ). The ratio of life forms of plants according to both classifications confirms the climatic conditions of the region - sharp-continental and arid climate, timed to the desert zone of Kazakhstan. There are 10 useful groups of plants: fodder - 110 species; technical -30 species; medicinal 48 species; melliferous — 13 species; ornamental -33 species; food - 33 species; vitamin — 11 species; poisonous - 32 species; insecticidal -8 species; soil-, forest- and phytomeliorative -11 species.
\end{abstract}

Keywords: chink Dongyztau, Aktobe region, flora, vascular plants, ecological group, life form, economic and useful species, practical application.

\section{Introduction}

The preservation of floristic diversity in Kazakhstan is an important task of our time, as defined by the Convention on the Conservation of Biological Diversity (1994) and the Nagoya Protocol on Access to Genetic Resources $(2010)$ [1,2].

In order to implement the provisions of the Convention, it is necessary to carry out an inventory of vegetation cover, especially for little studied regions, to determine the structural elements of flora, to assess the possibility of practical use of practical-valuable species of plants [3].

The bio morphological structure or spectrum of life forms of flora reflects the nature of the plant's adaptations to a set of environmental conditions in a certain physical and geographical area. Therefore, its analysis serves as a reliable tool for understanding the environmental parameters of a variety of habitats in a particular territory.

Chink Dongyztau (Aktobe region, the Western Kazakhstan) is a unique low-level region located at the junction of Aktobe, Atyrau and Mangystau regions, and is the northern mouth of Ustyurt [4]. Earlier floristic studies on the territory of West Kazakhstan [5-11] did not cover Dongyztau, so the natural flora of this region remained not studied.

The purpose of this study is to analyze the ratio of life forms, ecological groups and economic-valuable species of plants chink Dongystau.

\section{Methodology}

The subjects of the research were vascular plants Chink Dongyztau. Identification of species composition was carried out on the basis of own field gathering of 2017-2019, previously collected herbal materials of the Institute of Botany and Phytointroduction, Mangyshlak experimental botanical garden, Botanical institute named after V.L. Komarov. Based on the results of the analysis, a list of vascular plants of the investigated territory was compiled.

Allocation of vital forms of plants was carried out on the basis of a technique, developed by I.G. Serebryakov (trees, bushes, low shrubs, semi-bushes, semi-low shrubs, long-term herbs, biennial plants, annual plants, ephemeral plants) $[12,13]$ and C. Raunkiaer (phanerophytes, chamephytes, hemicryptophytes, cryptophytes, therophytes) $[14,15]$.

Practical-valuable groups of species are identified according to the data of scientific publication [16-26]. 


\section{Results and discussion}

Chink Dongyaztau is located in the natural desert zone, is the northern part of Ustyurt. The territory is located in the south-western part of Aktobe region between $46^{\circ} 08^{\prime}-46^{\circ} 68^{\prime}$ st. and $56^{\circ} 13^{\prime}-57^{\circ} 60^{\prime}$ Ed. [4].

Studies have shown that 314 species of vascular plants belonging to 170 genera and 40 families grow in the area under study (Table 1).

$\mathrm{Table} 1$

Taxonomic characteristics of the vascular plants of chink Dongyztau

\begin{tabular}{|c|l|c|c|c|}
\hline No. & Name of taxon & Amount of families, pieces & Amount of genera, pieces & Amount of species, pieces \\
\hline 1 & Gnetopsida & 1 & 1 & 2 \\
\hline 2 & Monocots & 6 & 23 & 40 \\
\hline 3 & Eudicots & 34 & 45 & 272 \\
\hline & Total & 41 & 69 & 314 \\
\hline
\end{tabular}

Analysis of life forms according I.G. Serebryakov is presented in Table 2.

Ta b l e 2

Life forms of vascular plants of flora of chink Dongyztau (by I.G. Serebryakov)

\begin{tabular}{|c|c|c|c|}
\hline No. & Types of life forms & $\begin{array}{l}\text { Absolute number } \\
\text { of species, pieces }\end{array}$ & $\begin{array}{l}\% \text { from general com- } \\
\text { position of species }\end{array}$ \\
\hline \multirow[t]{5}{*}{1} & Woody species & 21 & \\
\hline & Trees & 1 & 0.3 \\
\hline & Upright bushes & 14 & 4.5 \\
\hline & Lianas bushes & 1 & 0.3 \\
\hline & Low shrubs & 5 & 1.6 \\
\hline \multirow[t]{3}{*}{2} & Semi-wood types & 43 & \\
\hline & Semi-shrubs & 26 & 8.3 \\
\hline & Semi-low shrubs & 17 & 5.4 \\
\hline \multirow[t]{8}{*}{3} & Semi-carpic herbs & 124 & \\
\hline & Core root & 39 & 12.4 \\
\hline & Long root & 40 & 12.7 \\
\hline & Short root & 3 & 0.9 \\
\hline & Turfious & 17 & 5.4 \\
\hline & Root offspring & 2 & 0.6 \\
\hline & Tuber forming & 7 & 2.2 \\
\hline & Bulbous & 6 & 1.9 \\
\hline \multirow[t]{4}{*}{4} & Monocarpic herbs & 123 & \\
\hline & Perennial, biennial & 4 & 1.3 \\
\hline & Annual long-vegetative & 89 & 28.3 \\
\hline & Ephemers & 28 & 8.9 \\
\hline
\end{tabular}

The results showed that the dominant component in life forms is perennial polycarpic herbs - 124 species $(39.5 \%)$, the second position is occupied by monocarpics, including perennial, biennial and annual 123 species (39.1\%). Woody forms occupy 21 species (Elaeagnus angustifolia L., Spiraea hypericifolia L., Nitraria sibirica Pall., Nitraria schoberi L. and others), accounting for $6.7 \%$ of the total flora composition of vascular plants. The bulk is occupied by shrubs; trees, as a life form of natural vegetation, are not present in the region, only 1 species - Elaeagnus angustifolia L.

A significant proportion of ephemeral species is 28 (8.9\%) (Anisanta tectorium (L.) Nevski, Ceratocephala falcata (L.) Pers., Ceratocephala testiculata (Crantz) Bess., Consolida rugulosa f. paradoxa (Bunge) Iranshahr., Alyssum desertorum Staph., Alyssum linifolium Stephan ex Willd., Alyssum stenostachyum Botsch. \& Vved., Chorispora tenella (Pall.) DC., Descurainia sophia (L.) Webb ex Prantl, Erysimum leucanthemum (Stephan ex Willd.), and long-root plants - 40 species, or $12.7 \%$ (Medicago falcata L., Melilotus officinalis (L.) Potus. and others).

This ratio is due to the fact that the chink Dongyaztau is located in the desert zone of Kazakhstan, characterized by acute moisture deficiency. Arid conditions allow for the successful existence of herbaceous 
plants with a short spring cycle of vegetation, as well as long-spring species adapted extracting moisture from deep soil horizons. The growth of wood molds is limited by narrow ecotopes along streams, temporary watercourses, in inter-axial downsides, in places with close occurrence of groundwater.

Semi-wood forms occupy 43 species (13.7\%) - Anabasis eriopoda (Schrenk) Benth. ex Volkens., Anabasis truncata (Schrenk) Bunge, Atriplex cana Ledeb., Arthrophytum lehmannianum Bunge and others. This is because semi-shrubs and semi-low shrubs are typical of arid habitats, and have quite a variety of adaptations to harsh living conditions, including salted soils and sands. The studied area is characterized by the pronounced heterogeneity of the vegetation cover associated with different types of soils, edaphic versions of the desert and the neighborhood with the steppe zone [5].

Analysis of life forms by C. Raunkiaer allowed determining the prevalence of therophytes - 119 species, which is $37.9 \%$ of the total species composition (Table 3 ).

Table 3

Life forms of vascular plants of the chink Dongystau according to C. Raunkiaer

\begin{tabular}{|c|l|c|c|}
\hline \multirow{2}{*}{ No. } & \multicolumn{1}{|c|}{ Life forms } & \multicolumn{2}{|c|}{ Amount of species } \\
\cline { 3 - 4 } & & Total & $\%$ \\
\hline \multirow{2}{*}{1} & I. Phanerophytes - Ph & 14 & 4.5 \\
\cline { 2 - 4 } & 1. Meso-phanerophytes (MP) & 2 & 0.6 \\
\cline { 2 - 4 } & 2. Micro-phanerophytes (M) & 7 & 2.2 \\
\cline { 2 - 4 } & 3. Nano-phaerophytes (N) & 5 & 1.6 \\
\hline 2 & II. Chameophytes (Ch) & 46 & 14.6 \\
\hline 3 & III. Hemicryptophytes (Hk) & 104 & 33.1 \\
\hline 4 & IV. Cryptophytes (Kr) & 31 & 9.9 \\
\hline 5 & V. Therophytes (Th) & 119 & 37.9 \\
\hline
\end{tabular}

A rather large percentage of therophytes can be explained by the involvement of weed and ephemeral annual plants in the study flora. The prevalence of this life form testifies to the aridity of the territory [5]. The families Amaranthaceae and Brassicaceae take the leading positions in terms of the number of therophytes (Table 4).

Spectra of life forms (according with C. Raunkiaer) of vascular plants in the chink Dongyztau by leading families

\begin{tabular}{|c|l|c|c|c|c|c|}
\hline \multirow{2}{*}{ No. } & \multirow{2}{*}{ Family } & \multicolumn{5}{|c|}{ Life forms, amount of species } \\
\cline { 3 - 7 } & & $\mathrm{Ph}$ & $\mathrm{Ch}$ & $\mathrm{Hk}$ & $\mathrm{Kr}$ & $\mathrm{Th}$ \\
\hline 1 & Amaranthaceae & 4 & 24 & - & - & 39 \\
\hline 2 & Asteraceae & - & 7 & 24 & 1 & 7 \\
\hline 3 & Brassicaceae & - & 1 & 9 & - & 19 \\
\hline 4 & Poaceae & - & - & 18 & 3 & 5 \\
\hline 5 & Fabaceae & 2 & 1 & 16 & 1 & 5 \\
\hline 6 & Boraginaceae & - & - & 6 & 2 & 8 \\
\hline
\end{tabular}

Slightly inferior to hemi-cryptophytes, they are 104 species, or $33.1 \%$ (see Fig.).

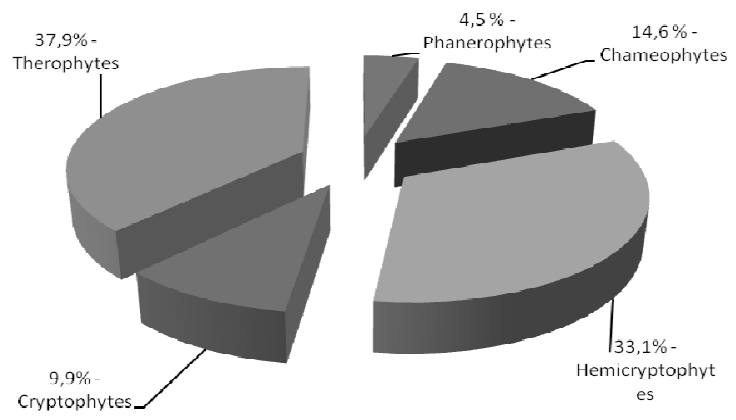

Figure. Ratio of life forms of vascular plants of chinca Dongyaztau flora (according to C. Raunkiaer) 
Among hemi-cryptophytes take the first place species from the family Asteraceae (Achillea santolinoides subsp. wilhelmsii (K. Koch) Greuter., Artemisia nitrosa Weber ex Stechm., Artemisia tomentella Trautv., Centaurea scabiosa subsp. adpressa (Ledeb.) Gugler, Centaurea squarrosa Willd., Cichorium intybus L., Cousinia astracanica (Spreng.) Tamamsch. And others); the next there are members of the family Poaceae (Agropyron desertorum (Fisch. ex Link) Schult., Agropyron fragile (Roth) P. Candargy., Alopecurus arundinaceus Poir., Colpodium humile (M.Bieb.) Griseb., Cynodon dactylon (L.) Pers., Elytrigia repens (L.) Nevski. And others) and Fabaceae (Astragalus lasiophyllus Ledeb., Astragalus lehmannianus Bunge., Glycyrrhiza aspera Pall., Glycyrrhiza glabra L., Medicago falcata L., Trigonella arcuata C.A. Mey., Melilotus albus Medik., Melilotus officinalis (L.) Pall., Onobrychis arenaria (Kit.) DC., Pseudosophora alopecurioides (L.) Sweet.) and others).

In third place are chameophytes. In this life form group take maximum positions species of family Amaranthaceae (Anabasis aphylla L., Anabasis cretaceae Pall.ex Benge., Anabasis eriopoda (Schrenk) Benth. ex Volkens., Anabasis truncata (Schrenk) Bunge., Anabasis turkestanica Korovin ex Iijin., Anabasis salsa (C.A. Mey.) Benth. ex Volkens., Arthrophytum lehmannianum Bunge, Camphorosma lessingii Litw., Halocnemum strobilaceum (Pall.) M. Bieb., Kalidium caspicum (L.) Ung.-Sternb., Kalidium foliatum (Pall.) Moq., Suaeda microphylla Pall., Suaeda physophora Pall.).

Further, cryptophytes adapted to carry an unfavorable season and having a supply of nutrients in underground organs are dispersed. These include species from family Liliaceae (Rhinopetalum karelinii Fisch., Tulipa biflora Pall., Tulipa schrenkii Regel.), Alliaceae (Allium caspium (Pall.) Bieb., Allium iliense Regel., Allium sabulosum Stev.ex Bunge.), Asparagaceae (Asparagus breslerianus Schult. et Schult.fil, Asparagus inderiensis Blum ex Pacz., Asparagus persicus Baker and others).

Phanerophytes are the smallest group to appear in the following species: Elaeagnus angustifolia L., Spiraea hypericifolia L., Nitraria schoberi L., Nitraria sibirica Pall., Anabasis gypsicola Iljin., Haloxylon ammodendron (C.A. Mey.) Bunge ex Fenzl., Haloxylon persicum Bunge., Salsola arbuscula Pall., Atraphaxis spinosa L., Tamarix elongata Ledeb., Tamarix hispida Willd., Tamarix laxa Willd., Tamarix ramosissima Ledeb.

At the last stage we analyzed the possibilities of practical use of plants Chink Dongyaztau. We have been allocated 10 economic-valuable groups (Table 5).

T a b l e 5

\section{Groups of Practical useful plants on the chink Dongyztau}

\begin{tabular}{|l|c|c|c|c|c|c|}
\hline Practical useful group & $\begin{array}{c}\text { Amount } \\
\text { of species, } \\
\text { pieces }\end{array}$ & $\begin{array}{c}\text { \% from } \\
\text { general amount } \\
\text { of species }\end{array}$ & $\begin{array}{c}\text { Amount } \\
\text { of genera, } \\
\text { pieces }\end{array}$ & $\begin{array}{c}\text { \% from } \\
\text { general amount } \\
\text { of genera }\end{array}$ & $\begin{array}{c}\text { Amount } \\
\text { of families, } \\
\text { pieces }\end{array}$ & $\begin{array}{c}\text { \% from } \\
\text { general amount } \\
\text { of families }\end{array}$ \\
\hline Feed & 110 & 35.0 & 69 & 40.5 & 19 & 47.5 \\
\hline Technical & 30 & 10.0 & 31 & 18.2 & 15 & 37.5 \\
\hline Medical & 48 & 15.0 & 46 & 27.0 & 23 & 57.5 \\
\hline Melliferous & 13 & 4.1 & 13 & 7.6 & 9 & 22.5 \\
\hline Ornamental & 33 & 11.0 & 30 & 17.6 & 17 & 42.5 \\
\hline Food & 33 & 11.0 & 26 & 15.2 & 14 & 35.0 \\
\hline Vitamin & 11 & 3.5 & 12 & 7.0 & 9 & 22.5 \\
\hline Poisonous & 32 & 10.1 & 23 & 13.5 & 16 & 40.0 \\
\hline Insecticidal & 8 & 2.5 & 8 & 4.7 & 7 & 17.5 \\
\hline $\begin{array}{l}\text { Soil-, forest- and } \\
\text { phytomeliorative }\end{array}$ & 11 & 4.0 & 7 & 4.1 & & 5 \\
\hline
\end{tabular}

The largest number of species is suitable as feed plants is 110 species, or $35.0 \%$ of the total species composition. These include plants such as Aeluropus littoralis (Gouan.) Parl., Agropyron desertorum (Fisch. ex Link) Schult., Elytrigia repens (L.) Nevski., Elytrigia repens (L.) Nevski., Lathyrus incurvus (Roth.) Willd., Melilotus officinalis (L.) Pall., Onobrychis arenaria (Kit.) DC. and others.

The second position is taken by medicinal plants is 48 species, or $15.0 \%$. Among this group are: Nitraria schoberi L., Capparis spinosa L., Amaranthus retroflexus L., Anabasis aphylla L., Suaeda physiophora Pall., Limonium gmelinii (Willd.) O. Kuntze, Rheum tataricum L., Nepeta pungens (Bunge) Benth., Artemisia austriaca Jacq., Cichorium intybus L. and others. 
On the third place there are 2 groups — ornamental and food plants, including 33 species $(11.0 \%)$. In the fourth place is poisonous plants -32 species $(10.1 \%)$, in the fifth is technical -30 species $(10.0 \%)$. The remaining groups are represented by a small number of species.

\section{Conclusion}

Thus, features of structural elements of flora of vascular plants of chink Dongyztau are defined, including analysis of life forms, ecological groups and practical-used species of plants.

The ratio of life forms according to C. Raunkiaer and I.G. Serebryakov is a confirmation of the specificity of this region - sharp-continental and arid climate. Thus, the analysis of life forms by C. Raunkiaer showed the prevalence of therophytes $(37.9 \%)$ and hemi-cryptophytes $(33.1 \%)$. The share of chametophytes $-14.6 \%$, cryptophytes -9.9 , phanerophytes $-4.5 \%$. This ratio of life forms brings this territory closer to the desert flora, as the high specific gravity of therophytes is characteristic of arid zones.

According to the classification of I.G. Serebryakov in the flora of chink Dongyaztau is dominated by herbaceous plants (124 species for herbaceous poly carpics and 123 species for herbaceous mono carpics). The high proportion of herbaceous plants and ephemera indicates arid habitat conditions.

10 valuable-useful groups of plants have been separated, which of them: fodder, medicinal, decorative and food plants occupy the leading positions.

\section{References}

1 Convention on Biological Diversity. - Rio-de-Janeiro, 1994. - 68 p.

2 Нагойский протокол регулирования доступа к генетическим ресурсам и совместного использования на справедливой и равной основе выгод от их применения к Конвенции о биологическом разнообразии. - ООН, 2010. - 30 с.

3 Бигалиев А.Б. Проблемы окружающей среды и сохранения биологического разнообразия / А.Б. Бигалиев. - Алматы: Қазақ ун-ті, 2005. - 126 с.

4 Физическая география Республики Казахстан: учеб. пос. / под ред. К.М. Джаналиевой. — Алматы: Қазақ ун-ті, 1998. $-265 \mathrm{c}$.

5 Сафронова И.Н. Пустыни Мангышлака (очерк растительности) / И.Н. Сафронова // Тр. Бот. ин-та РАН. — 1996. Вып. 18. - $211 \mathrm{c}$

6 Аралбай Н.К. Государственный кадастр растений Мангистауской области. Список высших сосудистых растений / Н.К. Аралбай, Г.М. Кудабаева, А.А. Иманбаева. — Актау, 2006. — 250 с.

7 Флора Казахстана. - Т. 1-9. - Алма-Ата: Наука, 1956-1966.

8 Агелеуов Е.А. К итогам изучения флоры и растительности Актюбинской области // Ботанические исследования Актюбинской области: сб. материалов межвуз. конф. / Е.А. Агелеуов, Н.У. Джакупова. — Актюбинск, 1992. — С. 9-14.

9 Айпеисова С.А. Растительность Актюбинского флористического округа / С.А. Айпеисова // Вестн. Актюб. гос. ун-та. - 2010. — № 1(42). - С. 42-48.

10 Иманбаева А.А. К изучению видового состава диких сородичей культурных растений Атырауской области / А.А. Иманбаева, М.Ю. Ишмуратова, А.Т. Туякова // Europaische Fachhochschule. — 2015. — № 7. - С. 5-11.

11 Мендыбаев Е.Х. Характеристика флоры степной зоны Западно-Казахстанской области / Е.Х. Мендыбаева // Вестн. Караганд. ун-та. Сер. Биология. Медицина. География. — 2010. — № 3(59). - С. $28-33$.

12 Серебряков И.Г. Жизненные формы высших растений и их изучение / И.Г. Серебряков // Полевая геоботаника. Т. 3. - М.; Л.: Наука, 1964. — С. 146-205.

13 Серебряков И.Г. Экологическая морфология растений / И.Г. Серебряков. - М.: Высш. шк., 1962. - С. 5-27.

14 Raunkiaer C. Plant life forms / C. Raunkiaer. — Oxford: Clarendon press, 1937. — 65 p.

15 Радкевич В.А. Экология / В.А. Радкевич. — Минск: Высш. шк., 1998. — 159 с.

16 Абышева Л.Н. Дикорастущие полезные растения России / Л.Н. Абышева, Л.М. Беленовская, Н.С. Бобылева. - СПб.: Изд-во СПХФА, 2001. - 663 с.

17 Берсон Г.З. Дикорастущие съедобные растения / Г.З. Берсон. — Л.: Гидрометеоиздат, 1991. — 72 с.

18 Миньков С.Г. Медоносные растения Казахстана / С.Г. Миньков. — Алма-Ата: Кайнар, 1974. — 204 с.

19 Журба О.В. Лекарственные, ядовитые и вредные растения / О.В. Журба, М.Я. Дмитриев. - М.: Колос, 2008. $512 \mathrm{c}$.

20 Соколов С.Я. Фитотерапия и фитофармакология / С.Я. Соколов. - М.: Мед. информ. агентство, 2000. - 953 с.

21 Растительные ресурсы России. Дикорастущие цветковые растения, их компонентный состав и биологическая активность. - T. 1-5. - М.: КМК, 2008-2012.

22 Кукенов М.К. Лекарства из растений / М.К. Кукенов, Л.М. Грудзинская, Н.Д. Беклемишев. - Алматы: Кітап, 2002. $-208 \mathrm{c}$.

23 Грудзинская Л.М. Аннотированный список лекарственных растений Казахстана: справоч. изд. / Л.М. Грудзинская, Н.Г. Гемеджиева, Н.В. Нелина, Ж.Ж. Каржаубекова. — Алматы, 2014. — 200 с.

24 Compendium of Medicinal and Aromatic Plants. Vol. II. Asia. — Triestre: ICS-UNIDO, 2006. — 305 p 
25 Ишмуратова М.Ю. Лекарственные растения народной медицины: учеб.-метод. пос. / М.Ю. Ишмуратова. — Караганда: Болашак-Баспа, 2014. - 137 с.

26 Муравьева Д.А. Фармакогнозия / Д.А. Муравьева, И.А, Самылина, Г.П. Яковлева. — М.: Медицина, 2002. - 415 с.

\author{
Ж.І. Куанбай, С.А. Абиев, В.Н. Тихомиров \\ Доңызтау шыңы флорасының кейбір құрылымдық \\ көрсеткіштерін зерттеу (Ақтөбе облысы)
}

\begin{abstract}
Мақалада Доңызтау шыңы флорасының түтікті өсімдіктерінің құрылымдық көрсеткіштерінің зерттеу қорытындысы берілген. И.Г. Серебряковтың тіршілік формасының классификациясына сай, өсімдіктердің басым бөлігіне, көпжылдық поликарпты өсімдіктерге - 124 түр немесе 39,5 \%, екінші орында монокарпты өсімдіктерге - 123 түр (39,5\%) жатады. Жартылай ағаштар - 43 түр немесе $13,7 \%$, ағаш - 21 түр (6,7\%). Эфемелердің үлесіне 28 түр $(8,9 \%)$ тиесілі. К. Раункиер классификациясы бойынша Доңызтау шыңы флорасының басым бөлігін терофиттер алып жатыр. Олардың үлесінде 119 түр. Пайыздық көрсеткіші - 37,9\%. Екінші орынға гемикриптофиттер орналасқан - 104 түр немесе 33,1 \%, үшіншіде хамефиттер - 46 түр (14,6 \%), төртіншіде криптофиттер - 31 түр немесе 9,9\%, бесіншіде фанерофиттер (14 түр, 4,5\%). Екі классификация бойынша тіршілік формаларының түрлік қатынасын зерттеу аймағының климат жағдайы Қазақстанның шөлді аймағында орналасқан шұғыл континетті және аридті климат екендігін дәлелдейді. Өсімдіктердің шаруашылықта маңызды 10 түрі: мал-азықтық - 110, техникалық - 30, дәрілік - 48 түр, балдық - 13, сәндік - 33, тағамдық - 33, дәрумендік - 11 , улы - 32, инсектицидті - 8, топырақ-, орман- және фитомелиоративті - 11 түрі тіркелген.
\end{abstract}

Кілт сөздер: Доңызтау шыңы, Ақтөбе облысы, флора, түтікті өсімдіктер, тіршілік формалары, шаруашылық-пайдалы түрлері, тәжірибеде қолдану.

\title{
Ж.И. Куанбай, С.А. Абиев, В.Н. Тихомиров \\ Изучение некоторых структурных показателей флоры чинка Донызтау (Актюбинская область)
}

\begin{abstract}
В статье представлены результаты исследования структурных показателей флоры сосудистых растений чинка Донызтау. Согласно классификации жизненных форм по И.Г. Серебрякову, преобладающую долю занимают многолетние поликарпические травы - 124 видов, или 39,5 \%, на второй позиции расположены монокарпические травы - 123 вида, или $39,1 \%$. Полудревесные виды составляют 43 вида, или $13,7 \%$, древесные формы - 21 вид, или 6,7\%. Отмечена высокая доля эфемеров - 28 видов, или 8,9\%. По классификации К. Раункиера, во флоре чинка Донызтау доминируют терофиты - 119 видов, или $37,9 \%$. На втором месте расположена группа гемикриптофитов - 104 вида, или $33,1 \%$; на третьем - хамефиты (46 видов, или 14,6 \%); на четвертом - криптофиты (31 вид, или $9,9 \%$; на пятом месте - фанерофиты (14 видов, или 4,5\%). Соотношение жизненных форм растений по обеим классификациям подтверждает климатические условия региона - резко-континентальный и аридный климат, приуроченный к пустынной зоне Казахстана. Выделены 10 хозяйственно-ценных групп растений: кормовые - 110 видов, технические - 30, лекарственные - 48, медоносные - 13, декоративные - 33, пищевые - 33, витаминные - 11 , ядовитые - 32, инсектицидные - 8, почво-, лесо- и фитомелиоративные - 11 видов.
\end{abstract}

Ключевые слова: чинк Донызтау, Актюбинская область, флора, сосудистые растения, экологическая группа, жизненная форма, хозяйственно-полезные виды, практическое применение.

\section{References}

1 Convention on Biological Diversity. (1994). Rio-de-Janeiro.

2 Nahoiskii protokol rehulirovaniia dostupa $k$ heneticheskim resursam i sovmestnoho ispolzovaniia na spravedlivoi $i$ ravnoi osnove vyhod ot ikh primeneniia $k$ Konventsii o biolohicheskom raznoobrazii [Nagoya Protocol on Access to Genetic Resources and Fair and Equitable Sharing of Benefits Arising from their Use to the Convention on Biological Diversity] (2010). UN [in Russian].

3 Bigaliev, A.B. (2005). Problemy okruzhaiushchei sredy i sokhraneniia biolohicheskoho raznoobraziia [Problems of environment and storage of the biological diversity]. Almaty: Qazaq universiteti [in Russian].

4 Fizicheskaia heohrafiia Respubliki Kazakhstan [Physical geography of Republic of Kazakhstan]. (1998). Almaty: Qazaq universiteti [in Russian]. 
5 Safronova, I.N. (1996). Pustyni Manhyshlaka (ocherk rastitelnosti) 「The deserts of Mangyshlak (review of vegetation)]. Trudy Botanicheskoho instituta RAN - Bulletin of Botanical Institute of RAS, 18, 211 [in Russian].

6 Aralbay, N.K., Kudabayeva, G.M., \& Imanbayeva, A.A. (2006). Hosudarstvennyi kadastr rastenii Manhistauskoi oblasti. Spisok vysshikh sosudistykh rastenii [The state cadastre of plants of Mangystau region. The list of higher vascular plants]. Aktau [in Russian; in Kazakh].

7 Flora Kazakhstana [Flora of Kazakhstan]. (1956-1966). (Vols. 1-9). Alma-Ata: Nauka [in Russian].

8 Ageleuov, E.A., \& Dzhakupova, N.U. (1992). K itoham izucheniia flory i rastitelnosti Aktiubinskoi oblasti [At the results of study of flora and vegetation of Aktobe region]. Proceedings from Botanical investigation of Aktobe region: Mezhvuzovskaia konferentsiia - Inter-institute conference. (pp. 9-14). Aktyubinsk [in Russian].

9 Aipeisova, S.A. (2010). Rastitelnost Aktiubinskoho floristicheskoho okruha [Vegetation of Aktobe Floristic District]. Vestnik Aktiubinskoho hosudarstvennoho universiteta - Bulletin of Aktobe State University, 1, 42, $42-48$ [in Russian].

10 Imanbayeva, A.A., Ishmuratova, M.Yu., \& Tuyakova, A.T. (2015). K izucheniiu vidovoho sostava dikikh sorodichei kulturnykh rastenii Atyrauskoi oblasti [To the study of species composition of wild relatives of cultivated plants of Atyrau region]. Europaische Fachhochschule, 7, 5-11 [in Russian].

11 Mendybayev, Ye.Kh. (2010). Kharakteristika flory stepnoi zony Zapadno-Kazakhstanskoi oblasti [Characteristics of flora of steppe zone of Western-Kazakhstan Region]. Vestnik Karahandinskoho universiteta. Seriia biolohiia, meditsina, heohrafiia - Bulletin of Karaganda University. Series Biology. Medicine. Geography, 3(59), 28-33 [in Russian].

12 Serebryakov, I.G. (1964). Zhiznennye formy vysshikh rastenii i ikh izuchenie [Life forms of plants and their study]. Polevaia heobotanika - Field Geobotany, 3, Moscow; Leningrad: Nauka [in Russian].

13 Serebryakov, I.G. (1962). Ekolohicheskaia morfolohiia rastenii [Ecological morphology of plants]. Moscow: Vysshaia shkola [in Russian].

14 Raunkiaer, C. (1937). Plant life forms. Oxford: Clarendon press.

15 Radkevich, V.A. (1998). Ekolohiia [Ecology]. Minsk: Vysshaia shkola [in Russian].

16 Abysheva, L.N., Belenovskaia, L.M. \& Bobyleva, N.S. (2001). Dikorastushchie poleznye rasteniia Rossii [Wild useful plants of Russia]. Saint-Petersburg: Publ. of Saint-Petersburg Chemical and Pharmaceutical Academy [in Russian].

17 Berson, G.Z. (1991). Dikorastushchie sedobnye rasteniia [Wild food plants]. Leningrad: Hidrometeoizdat [in Russian].

18 Minkov, S.G. (1974). Medonosnye rasteniia Kazakhstana [Meadow plants of Kazakhstan]. Alma-Ata: Kainar [in Russian].

19 Zhurba, O.V., \& Dmitriev, M.Ya. (2008). Lekarstvennye, yadovitye i vrednye rasteniia [Medicinal, poisonous and harmful plants]. Moscow: Kolos [in Russian].

20 Sokolov, S.Ya. (2000). Fitoterapiia i fitofarmakolohiia [Phytotherapy and phytopharmacology]. Moscow: Medical Informative Agency [in Russian].

21 Rastitelnye resursy Rossii. Dikorastushchie tsvetkovye rasteniia, ikh komponentnyi sostav i biolohicheskaia aktivnost [Vegetable resources of Russia. Wild flower plants, their component composition and biological activity]. (Vols. 1-5). (2008-2012). Moscow: KMK [in Russian].

22 Kukenov, M.K., Grudzinskaya, L.M. \& Beklemishev, N.D. (2002). Lekarstva iz rastenii [Medical preparations from plants]. Almaty: Kitap [in Russian].

23 Grudzinskaya, L.M., Gemedzhieva, N.G., Nelina, N.V., \& Karzhaubekova, Zh.Zh. (2014). Annotirovannyi spisok lekarstvennykh rastenii Kazakhstana [Annotated list of medicinal plants in Kazakhstan]. Almaty [in Russian].

24 Compendium of Medicinal and Aromatic Plants. (2006). (Vol. II. Asia). Triestre: ICS-UNIDO.

25 Ishmuratova, M.Yu. (2014). Lekarstvennye rasteniia narodnoi meditsiny [The herbs of folk medicine]. Karaganda: BolashaqBaspa [in Russian].

26 Muraveva, D.A., Samylina, I.A., \&, Yakovlev, G.P. (2002). Farmakohnoziia [Pharmacognosy]. Moscow: Meditsina [in Russian]. 